1953, and includes more university theses than the first two volumes. Entries are arranged by subject according to the Universal Decimal Classification and alphabetically by the names of authors; in this latest volume the rules used in the "World List of Scientific Periodicals" have been adopted for abbreviation of titles of periodicals. There are an author index and a supplementary list of Egyptian periodicals.

Science and Management: Conference in Harrogate

THE British Institute of Management will hold its national conference this year at Harrogate during November 2-4, the general theme being "The Impact of Science on Management in the Future". Among the subjects to be discussed are : training science and engineering graduates for industry; electronic processing of data; development of tools of production; operational research ; the research associations ; automation ; human implications of technical innovation; use of radioactive isotopes ; and training scientists for management. Stress will be laid throughout the Conference on the need to translate new scientific discoveries into immediate and practical day-to-day effect. Twenty-four sectional meetings will be held during the two full days of the conference ; these will be arranged so that five or six will be held simultaneously, and, in effect, delegates will be able to attend five meetings altogether, at each of which there will be a choice of about half a dozen topics. On the evening of November 3 there will be a choice of sixteen discussion groups, each devoted to a topic currently attracting widespread attention in management circles. Altogether about a thousand persons will be attending the conference. The fee is £9. Further information can be obtained from the Institute at Management House, 8 Hill Street, London, W.1.

\section{Fresh-water Biology in Scotland}

A TWO-DAY meeting is being arranged for April $9-10,1956$, by the Institute of Biology (Scottish Branch), to be held in the Zoology Department of the University of Glasgow. There will be three halfdays for papers and a half-day excursion to the University's Field Station at Rossdhu, Loch Lomond. The subjects will be: chemistry of fresh waters; plants as indicators of fish productivity; bottom fauna and bottom deposits; erosion products as affecting the river regime; fish parasites; molluses; amphibia; trout; char; powan; pike; coastal migration of salmon; endocrines of salmonids ; the work of the Salmon Inspectorate, that of the North of Scotland Hydro-Electric Board and that of the Brown Trout Research Laboratory, Faskally. Further information will be available in due course from Dr. R. M. Gorrie, "Balnagowan", Murrayfield Drive, Edinburgh, who is secretary of the Scottish Branch of the Institute of Biology.

\section{Announcements}

WE regret to record the death on September 29 of Prof. H. M. Turnbull, F.R.S., emeritus professor of morbid anatomy in the University of London, aged eighty.

Prof. P. M. S. BLACKetT, professor of physics, Imperial College of Science and Technology, London, and Mr. H. Douglass, general secretary of the Iron and Steel Trades Confederation, have been appointed members of the Advisory Council for Scientific and
Industrial Research. Mr. J. Crawford, Prof. T. R. C. Fox and Sir George Thomson have retired from the Council on completion of their terms of office.

Mr. Stephen Cheveley, chairman of the Central Agricultural Control, Imperial Chemical Industries, Ltd., has been appointed by the Minister of Agriculture, Fisheries and Food and the Secretary of State for Scotland to be chairman of the Governing Body of the Foot-and-Mouth Disease Research Institute, Pirbright, Surrey, in succession to Prof. Wilson Smith, who is retiring.

A confERence on "Raw Cotton-its Properties and Distribution" has been arranged by the Textile Institute and will be held in the Walker Art Gallery, Liverpool, on November 23. The speakers and their subjects are: Prof. S. C. Harland (University of Manchester) on genetics; E. Lord (British Cotton Industry Research Association) on cotton quality; Allan Draper (William Birtwistle Allied Mills, Ltd.) on spinners' requirements ; and W. B. Hutchinson (Major Cleaver and Co.) on marketing. Further information can be obtained from the General Secretary, Textile Institute, 10 Blackfriars Street, Manchester 3.

A ONE-DAY symposium on chromatography will be held at Hatfield Technical College, Roe Green, Hatfield, Herts, on November 4. Four papers will be read, as follows : principles of chromatography (Dr. A. J. P. Martin), inorganic chromatography (Dr. F. H. Pollard), paper electrophoresis (Dr. A. B. Foster) and vapour-phase chromatography (H. N. Wilson). Tickets for the symposium are available on application to the College.

THe British Institute of Recorded Sound, in conjunction with the Department of Extra-Mural Studies of the University of London, has arranged for six lectures to be given by Mr. Eric Simms on "The Language of Birds and other Animals". The first lecture was given on October 4, and the others will be given on alternate Tuesdays (7 p.m.) at fortnightly intervals from that date. The fee is $10 s$. the course or $2 s$. $6 d$. each lecture. On January 25 at 7.30 p.m., Dr. W. H. George will give a lecture (fee 2s. 6d.) on "Pianists" Touch-its Scientific Study". All the lectures will be at the Institute premises, 38 Russell Square, London, W.C.I, whence further information can be obtained.

THe Department of Agriculture for Scotland has awarded the following postgraduate scholarships in husbandry, tenable for periods up to three years: A. D. Drysdale (University of Cambridge), Miss C. J. Falconer (University of Reading), David M. S. Livingston (University of Aberdeen and Low Temperature Research Station, Cambridge), R. A. N. Napier (University of Edinburgh) and Charles Smith (Iowa State College). In addition, the following current awards are being continued for a further period: I. C. Beattie, J. Frame and W. C. Smith (Massey Agricultural College, New Zealand), I. A. Munro (University of Reading) and T. M. Sutherland (Iowa State College).

THE Association of British Chemical Manufacturers (Cecil Chambers, 86 Strand, London, W.C.2) has recently published "British Chemicals and their Manufacturers, 1955" (pp. 192), which lists about twelve thousand products with the names and addresses of the manufacturers. The book is available free to persons or firms interested in the purchase of chemicals on application to the Association. 